\title{
Discussion on structural evolution of Mesozoic Peninsular Malaysia
}

\author{
Journal, Vol. 147, 1990, pp. 11-26
}

W. Altermann writes: In their discussion of palaeotectonics and palaeogeography of Malay Peninsula, Harbury et al. propose an alternative interpretation to Şengör's (1984) model of Triassic or early Jurassic collision of the Cimmerian (Sibumasu) block with the Indochina block in the east. Their interpretation depicts Malay Peninsula as part of Triassic and lower Jurassic Australian Gondwana. The Raub Bentong Fault Zone is considered as having originated through the Permo-Triassic southward destruction of 'Tethys Ocean II' underneath the Malay Peninsula. For the Triassic this zone is described as a normal fault (see figs 11-13, Harbury et al.).

The Raub Bentong Zone, however, is generally accepted to be the southern extension of the Nan-Uttaradit suture in north Thailand (see Harbury et al., fig. 2). This suture was described by Macdonald \& Barr (1984) as having a volcanic arc setting. Macdonald et al. (1985) reported crossite blueschists associated with ultramafic and mafic rocks from this suture. Barr \& Macdonald (1987) identified type II ophiolites, formed by a spreading process above a subduction zone in this suture, and also reported a $\mathrm{K}$-Ar metamorphic age of $269 \pm 12 \mathrm{Ma}$ for the crossite schists. Helmcke (1985) reported a K-Ar age of $344 \pm 22 \mathrm{Ma}$ for the ultramafic and mafic rocks included in the suture. None of. these references are cited in the palaeogeographic discussion by Harbury et al.

Helmcke $(1983,1985$, 1986a, 1986b), Helmcke \& Kraikhong (1982), Helmcke \& Lindenberg (1983) and Altermann (1983, 1986, 1987, 1989), Altermann et al. (1983), Winkel et al. (1983) proposed that the main orogeny in Southeast Asia was late Palaeozoic (Carboniferous and/or Permian) rather than Triassic. Although these models discuss the Sibumasu block as welded to Palaeoeurasia already in the Permian, this possibility is completely ignored by Harbury et al., who still maintain that the Southeast Asia is generally thought to have experienced a major Triassic orogeny. In their palaeogeographic discussion these authors argue that there is no evidence for a major Triassic/Jurassic orogeny and therefore Peninsular Malaysia, Thailand and Burma were not attached to central and east Thailand and Indochina until after Middle Jurassic or Cretaceous. This shows only that the attachment was not Early Mesozoic. Data on Palaeozoic rocks, presented by Harbury et al. support Helmcke's (1985) interpretation.

Palaeontological evidence for a close Eurasian relationship of the terranes discussed, as presented by Bunopas \& Vella (1984), Walchia piniformis from south Thailand; by Ingavat-Helmcke \& Helmcke (1986), Permian foraminifera with Euramerican affinities; by Buffetaut \& Ingavat (1985), Eurasian Triassic land vertebrates from east Thailand; by Fontaine (1986), Permian corals from Sumatra, known also from south China, Yunnan, Thailand and Laos; by Grant (1976), warm water Permian brachiopods from southern Thailand, are not considered by Harbury et al. Discussion of such evidence as well as of tectonic, sedimentologcial and other arguments can be found, for instance, in Metcalfe
(1986). Although these arguments may be equivocal, to ignore them in the discussion of palaeontological data is a mistake, while the hint that palaeomagnetic data may in future, help to solve the problem is little value in the present controversy. The suggestion by Audley-Charles (1987) that Cathaysian flora may not have been geographically isolated from Gondwana, but reflects warmer Tethyan conditions along eastern Gondwana is highly speculative and not sufficient argument for Jurassic drift and Cretaceous collision.

The palaeontological problems generated by a Jurassic Gondwana provenance of Malay Peninsula as proposed by Harbury et al. are serious and their discussion would require a separate paper. In addition there are the questions to be answered: where is the suture of the post-Jurassic collision and what kind of Tethys was destroyed during this event?

The publications cited by Harbury et al., selectively support the hypothesis presented. Thus Stauffer (1974) is cited, but there is no reference to Stauffer (1983), where a Triassic orogeny is proposed. The paper of Metcalfe (1986) seems forgotten, in which Audley-Charles' (1983) plate tectonic reconstruction is judged to be untenable and the 'change from cold water faunas with NW Australian affinities to warmer water faunas with Eurasian affinities in the Lower to Middle Permian transition on the Sibumasu Block' is tough to support Helmcke's hypothesis (Metcalfe, 1986, p.160-161).

The first report of exclusively extensional tectonics during the Triassic in Southeast Asia has to be credited to Cooper et al. (1989). These authors described a complex system of extensional basins east of the Nan Uttaradit Suture and proposed a plate tectonic model for the Permian to Cretaceous evolution of Thailand. In the Triassic the development of continental half-grabens and intermontane basins followed the Indosinian Orogeny.

Although two of the co-authors of Harbury's et al.'s paper (M. G. Audley-Charles and I. Metcalfe) criticized Helmcke's conclusion that the main orogeny in southeast Asia was late Palaeozoic, on page 20 of Harbury et al's. paper we read 'The Permian deformation with metamorphism was far more severe than that which deformed the Triassic and Jurassic strata' and on page 23 'The oldest affected rocks are of pre-Upper Permian, and are characterized by complex refolded structures, multiple cleavage and metamorphic assemblages.... These events are closely associated with the early phase of Permo-Triassic granite intrusion, and represent the major orogeny that affected the Peninsula'. Changing the opinion with increasing knowledge is a normal process in science but why then is no reference made to Helmcke and his co-authors?

The writer trusts that this discussion will contribute to objectivity and to a better understanding of the geology of Peninsular Malaysia.

N. A. Harbury, M. E. Jones, M. G. Audley-Charles \& K. R. Mohamed reply: any interpretation of the palaeo- 
geography of this region is likely to need revision as new exposures are found and studied, stratigraphically sensitive fossils are discovered and palaeomagnetic data coverage is improved. The region being discussed is submerged for a large part in rainforest, wet tropical weathering rapidly destroys the details of new exposures and detailed field mapping coverage is far from complete. The area of the region under discussion measures approximately $350 \mathrm{~km}^{2}$ so that correlations of structural features, especially the so-called regional sutures is tentative at best. The correlation of the northern and southern parts of the Raub-Bentong Fault zone are not, in our view, as definitive as Altermann suggests. To give the flavour of palaeographical uncertainty it can be noted that whilst some palaeomagnetic work (Haile et al. 1983; Fuller et al. 1990) indicates that most of mainland SE Asia and Borneo have rotated anticlockwise during the Neogene, others (Maranate \& Vella 1986) claim their studies indicate rotation has been clockwise. In these circumstances to refer to what interpretations are generally agreed may not be very strong support for a particular view.

Our paper is intended primarily to present the results of field investigations in part of the Peninsular Malaysia which were mainly structural. Some of the Journal referees and those to whom we sent the paper for review before we submitted it, suggested we should keep the palaeographical content of the paper to a minimum because there exist so many uncertainties. We attempted to follow this advice and for this reason we kept the section on palaeotectonics and palaeogeography to a minimum. Our references to palaeography were focused on those directly concerned with Peninsular Malaysia. Altermann is correct in saying we neglected to deal comprehensively with the palaeogeographical literature for SE Asia. We doubt he is correct in suggesting we operated a selective bias in our choice of references; several views contrary to ours were cited (e.g. Mitchell 1981; Şengör 1986 and others).

Specifically, we note that, with the one exception of a paper by Stauffer (1983), Altermann refers to work in Thailand, Sumatra, Yunnan, Laos, China, whereas our paper was concerned with the Malyasian part of Peninsular Malaysia. We are aware that there seem to be strong differences in stratigraphy and structure between adjacent parts of SE Asia (Metcalfe 1988). In our view the paper by Tan (1984) describing the extensional nature of the Triassic central basin of Peninsular Malaysia is more relevant to our study than the later paper by Cooper et al. (1989) dealing with Thailand which appeared after our paper was in press.

The presence of Triassic land vertebrates cited by Altermann in east Thailand presents more of a problem than he admits. Such vertebrates have not yet been found in the lithologically similar terrestrial deposits of Peninsular Malaysia despite considerable searching there. Altermann's claim that we 'maintain the Southeast Asia is generally thought to have experienced a major Triassic orogeny' is misleading. We tried to make clear that several authors had cited evidence and arguments for Triassic orogeny, but we attempted to show that such an orogeny appears to be absent from Peninsular Malaysia. We noted that Wolfart (1987) from field mapping in Western Thailand had found evidence for a late Permian orogeny there, even though we omitted to record that earlier papers by Helmcke and by Altermann and some other workers had come to similar conclusions from their work in Thailand.

The main thrust of our paper is that the field exposures we studied in Peninsular Malaysia indicated that in this
Peninsula the last two notable deformation events were in the late Permian and late Cretaceous. We tried to make it clear that we had not investigated other parts of mainland SE Asia. We are interested to note that Helmcke's interpretation based on his studies in Thailand is consistent with our view of the date of deformation events. However, we tried to emphasize that the late Cretaceous deformation in Peninsular Malaysia while producing a cleavage, was relatively minor event and did not appear to have been related to a mountain building type of event.

Despite these differences, Altermann is correct to question our palaeogeographical interpretation. Metcalfe (1990) has presented a good case for Sibumasu (part of Peninsular Malaysia, Thailand and Sumatra) having rifted from Australian Gondwana in the Middle Permian. He proposed it collided with Indochina and east Malaysia within Tethys during the late Permian. In his model the rifting event that affected northern Australia during the late Jurassic probably involved parts of Burma and western Sumatra. We consider this latest view is more consistent with available information.

I. Metcalfe replies: The paper by Harbury et al. (1990) principally presents structural data which indicates that there was in fact no Late Triassic deformational event in Peninsular Malaysia, the last major phase of deformation having occurred in the Late Permian followed by a milder deformational phase in the mid-late Cretaceous. Altermann's discussion centres upon the palaeotectonics and palaeogeography section of the paper, which is the shortest and weakest section, and upon which there was disagreement among the authorship. At the outset I would like to state that I do not ascribe to the proposals made in that section. It is well known amongst those working on the palaeogeography of Southeast Asia that I have long argued against a Jurassic rifting of Sibumasu from Gondwana-Land and have repeatedly argued for an early Permian rifting and a Permo-Triassic suturing of this block to Indochina (Metcalfe 1986, 1988, and 1990).

The Malay Peninsula can be divided into two parts by the Raub-Bentong suture, the western part belonging to the Sibumasu block and the eastern part to the East Malaya block. The Bentong-Raub suture comprises an approximately $13 \mathrm{~km}$ wide zone of schists, cherts and siliciclastics with serpentinites and melanges (Tjia 1989) that are exposed along the western margin of the Central Basin of the Peninsula in which accumulated thick Middle and Upper Triassic volcaniclastic sediments. Melange in the Raub area contains limestone clasts that yield Lower and lower Upper Permian microfossils indicating an Upper Permian or Lower Triassic age for the mélange (Chakraborty \& Metcalfe 1987) Since the Triassic rocks of the Peninsula generally exhibit open, upright folds whereas the Carboniferous-Permian rocks are polyphasely deformed, the age of suturing of western and eastern Peninsular Malaysia can be constrained as latest Permian-earliest Triassic. This age is comparable to that of the 'Variscan' orogeny as proposed by Helmcke and co-workers and to the age of suturing between 'Shan-Thai' and Indochina recently proposed by Cooper $\boldsymbol{e t}$ al. (1989) which caused deformation referred to by them as the 'Indosinian' Orogeny. I have further argued (Metcalfe $1988,1990)$ that this suturing took place within the Tethys ocean. I disagree that the first report of exclusively extensional tectonics during the Triassic in Southeast Asia was made by Cooper et al. (1989); that claim must rest with Tan (1976) who proposed an aborted rift model for the 
Malay Peninsula.

I find it severe of Altermann to accuse Harbury et al. of selective referencing in support of their hypothesis since views contrary to that presented were cited (Şengör 1986; Mitchell 1981; Metcalfe 1988). I agree with Altermann that Harbury et al. should not have overlooked the work of Helmcke and co-workers in Thailand and would like to point out that in my own writings on Southeast Asian palaeogeography this is not the case. My previous challenge to Helmcke's interpretation of the Permian sequence in the Nam Duk Basin centred chiefly on the use of the terms 'flysch' and 'molasse' in an Alpine sense to what I did, and still do, consider a relatively shallow intracratonic basin. This 'criticism' was also made at a time when I believed that a Late Triassic suturing of Sibumasu and Indochina was still a strong possibility based on available data. It seems strange that Altermann should condemn others for expressing differing viewpoints, a practice he indulges in and which is usual in academia! Changing opinion with increasing knowledge is indeed a normal process!

\section{References}

Altermann, W. 1983. Sedimentology of the Permian Molasse-type strata along the Lom Sak-Chum Phae highway (Petchabun-Province). In: Thanasuthipitak, T. (ed.) Proceedings of the Annual Technical Meeting 1982. Chiang Mai, Thailand, 53-63.

- 1986. The Upper Paleozoic pebbly mudstone facies of Peninsular Thailand and Western Malaysia-Continental margin deposits of Paleoeurasia. Geologische Rundschau, 75/2, 79-89.

- 1987. The Permo-Carboniferous Facies Development in Thailand: A plate tectonic discussion. Abstracts, XIth International Congress of Carboniferous Stratigraphy and Geology, Beijing, 1987, Symposium 5, 393-394.

- 1989. Facies development in the Permian Petchabun Basin, Central Thailand. VWB-Verlag für Wissenschaft und Bildung, Berlin.

-, Grammel, S., Ingavat, R., Nakornsri, N. \& Helmcke, D. 1983. On the evolution of the Palaeozoic terrains bordering the northwestern Khorat Plateau. Conference on Geology and Mineral Resourses of Thailand. Section A-Geology. Bangkok, Nov. 1983,1-5pp.

Audley-Charles, M. G. 1983. Reconstruction of the eastern Gondwanaland. Nature, 310, 165-166.

- 1987. Dispersal of Gondwanaland: relevance on the evolution of the angiosperms. In: WhITMORE, T. C. (ed.) Biogeography of the Malay Archipelago. Oxford Monographs on Biogeography, 4, Clarendon Press, Oxford, 5-25.

BARR, S. M. \& MACDONALD, A. S. 1987. Nan River suture zone, northern Thailand. Geology, 15, 907-910.

Bunopas, S. \& Vella, P. 1984. Phuket-Khaeng Krachan Groups, a rifted continental margin deposit with effect of ice-rifting megaclasts from Gondwana. Abstract, GEOSEA V, Kuala Lumpur, 9-13 April, 1984.

Buffetaut, E. \& InGAVAT, R. 1985. The Mesozoic vertebrates of Thailand. Scientific American, 253/2, 80-87.

Chakraborty, K. R. \& MetCalfe, I. 1987. Occurrence of sheared diamictite in the Raub area, its possible extensions and tectonic implications. Geological Society of Malaysia Annual Conference 1987, Abstracts, Warta Geologi, 13, 62-63.

CoOper, M. A., Herbert, R. \& HiLl, G. S. 1989. The structural evolution of Triassic intermontane basins in northeastern Thailand. International Symposium on Intermontane Basins: Geology \& Resources, Chiang Mai, Thailand, 231-242.

Fontaine, H. 1986. Discovery of Lower Permian corals in Sumatra. Bulletin of the Geological Society of Malaysia 19, 183-191.

Grant, R. E. 1976. Permian Brachiopods from southern Thailand. Journal of Paleontology, 50, 1I/II, supplement No. 3, Paleontological Society Memoirs.

Haile, B. S., Beckinsale, R. D., Chakraborty, K. R., Hussien, A. H. \&
Hardjono, T. 1983. Palaeomagnetism, geochronology and petrology on the dolerite dykes and basaltic lavas from Kuantan, West Malaysia. Bulletin of the Geological Society of Malaysia, 16, 71-85.

Harbury, N. A., Jones, M. E., Audley-Charles, M. G., Metcalfe, I. \& Mohamed, K. 1. 1990. Structural evolution of Mesozoic Peninsular Malaysia. Journal of the Geological Society, London, 147, 11-26.

HELMCKE, D. 1983. On the Variscan evolution of Central Mainland Southeast Asia. Earth Evolution Sciences, 4/1982, 309-319.

1985. The Permo-Triassic "Paleotethys" in Mainland Southeast Asia and adjacent parts of China. Geologische Rundschau. 74/2, 215-228.

1986a. On the geology of the Petchabun Fold Belt (Central Thailand)-implications for the geodynamic evolution of Mainland S.E. Asia. In: TeH, G. H. \& Paramananthan, S. (eds) GEOSEA V Proceedings, Vol. I, Bulletin of the Geological Society of Malaysia, 19, 79-85.

- 1986b. Die Alpiden und die Kimmeriden: Die verdoppelte Geschichte der Tethys-Discussion. Geologische Rundschau. 75/2, 495-499.

- \& KRAIKHONG, C. 1982. On the geosynclinal and orogenic evolution of Central and Northeastern Thailand, Journal Geological Society of Thailand, 5, 52-74.

- \& LindenberG, H.-G. 1983. New data on the "Indosinian" Orogeny from Central Thailand. Geologische Rundschau. 72/1, 317-328.

ingavat-Helmcke, R \& Helmcke, D. 1986. Permian fusulinacean faunas of Thailand-event correlated evolution. In: WALLISER, O. H. (ed.) Lecture notes in Earth sciences, 8, Global bio-events. Springer Verlag, Berlin, 241-248.

Macdonald, A. S. \& Barr, S. M. 1984. The Nan River mafic-ultramafic belt, Northern Thailand: Geochemistry and tectonic signification. Bulletin of the Geological Society of Malaysia, 17, 209-224.

Fuller, M., Haston, R. \& Almasco, J. 1990. The paleomagnetism of the Zambales Ophiolite. Tectonophysics In press.

- - Yaowanomothin, W. \& Panjasawatwong, Y. 1985. Blue schist-mafic-ultramafic complexes of the Nan River Belt, Northern Thailand. Geological Society of Thailand Newsletter, 17/5-6, 25.

Maranate, S. \& Vella, P. 1986. Paleomagnetism of the Khorat Group, Mesozoic, Northwest Thailand. Journal SE Asian Earth Sciences, 1, 23-31.

MetCalfe, I. 1986. Late Paleozoic paleogeography of Southeast Asia: Some stratigraphical, paleontological and paleomagnetic constrains. Bulletin of the Geological Society of Malaysia, 19, 153-164.

- 1988. Origin and assembly of south-east Asian continental terranes. In: Audley-Charles, M. G. \& Hallam, A. (eds) Gondwana and Tethys. Geological Society, London, Special Publication, 37, 79-100.

- 1990. Allochthonous terrane processes in Southeast Asia. Philosophical Transactions of the Royal Society of London, A331, 625-

Mrtchell, A. H. G. 1981. Phanerozoic plate boundaries in mainland S.E. Asia, the Himalayas and Tibet. Journal of the Geological Society, London, 138, 109-122.

ŞEngör, A. M. C. 1984. The Cimmerides of eastern Asia: history of the eastern end of Paleo-Tethys. Memoirs de la Societe Geologique de France, 147, 139-167.

- 1986. The dual nature of the Alpine-Himalayan system: progress, problems and prospects. Tectonophysics, 127, 177-195.

STAuFfer, P. H. 1974. Malaya and south-east Asia in the pattern of continental drift. Bulletin of the Geological Society of Malaysia, 7, 79-88.

- 1983. Unraveling the mosaic of Paleozoic crustal blocks in Southeast Asia. Geologishe Rundschau, 72/3, 1061-1080.

TAN, B. K. 1976. Tectonic development of Peninsular Malaysia (Abstr.). Geological Society of Malaysia Discussion Meeting, Ipoh, December 1976. Abstracts of Papers.

— 1984. Tectonic framework and evolution of the Central Belt and its margins, Peninsula Malaysia. Bulletin of the Geological Society of Malaysia, 17, 307-322.

Tuia, H. D. 1989. The Bentong Suture. In: Sirumorang, B. (ed.) Proceedings of th Regional conference on Geology, Mineral and Hydrological Resources SE Asia, 73-85.

Winkel, R., Ingavat, R. \& Helmcke, D. 1983. Facies and stratigraphy of the Lower-lower Middle Permian strata of the Petchabun Fold Belt in Central Thailand. Workshop on Stratigraphy and Correlation of Thailand and Malaysia Had Yai, Thailand, Sept. 1983, 293-306.

Wolfart, R. 1987. Geology of Amphoe Sop Prap and Amphoe Wang China Thailand. Geolgisches Jahrbuch, B65, 3-52.

Wladyslaw Altermann, Department of Geology, University of Stellenbosch, 7600, R.S.A. N. A. Harbury, Department of Geology, Birkbeck College, London W1P 1PA, UK.

M. E. Jones, M. G. Audley-Charles \& K. R. Mohamed, Department of Geological Sciences, University College London, Gover Street, London WCIE 6BY, UK

I. Metcalfe, Department of Earth Sciences, Parks Road, Oxford OX1 3PR, UK. 